\title{
Ignaz Goldziher'in ‘İslam Kültürü ve Araştırmaları I-II’ Eseri Bağlamında Hz. Peygamber ve Hadisler Hakkındaki Görüşlerine Yeniden Bakış*
}

\section{Revisiting Ignaz Goldziher's Views on the Prophet and Hadiths in the Context of 'Islamic Culture and Studies I-II'}

\author{
İlyas CANIKLi \\ Doç. Dr., Ankara Yıldırım Beyazıt Üniversitesi, İlami Illimler Fakültesi, Hadis Anabilim Dalı \\ Associate Professor, Ankara Yıldırım Beyazıt University, Faculty of Islamic Science, Department of Hadith \\ Ankara, Turkey \\ ilyascanikli@gmail.com \\ orcid.org/0000-0001-9340-7982
}

\author{
Makale Bilgisi / Article Information \\ Makale Türü / Article Types \\ : Araştırma Makalesi / Research Article \\ Geliş Tarihi / Received \\ : 28 Ağustos / August 2020 \\ Kabul Tarihi / Accepted \\ :24 Eylül / September 2020 \\ Yayın Tarihi / Published \\ : 15 Aralık / December 2020 \\ Yayın Sezonu / Pub Date Season : Aralık / December \\ Cilt / Volume: 7 - Sayı / Issue: 2 - Sayfa / Pages: 339-364 \\ Atıf / Cite as \\ Canikli, Illyas. "Ignaz Goldziher'in 'ślam Kültürü ve Araştırmaları I-II' Eseri Bağlamında Hz. Peygamber ve Hadisler \\ Hakkındaki Görüşlerine Yeniden Bakış". Bülent Ecevit Üniversitesi Illahiyat Fakültesi Dergisi 7/2 (2020), 339-364. \\ Doi: $10.33460 /$ beuifd. 787286 \\ İtihal / Plagiarism \\ Bu makale, en az iki hakem tarafından incelendi ve intihal içermediği teyit edildi. \\ This article has been reviewed by at least two referees and scanned via a plagiarism software. \\ Yayın Hakkı / Copyright ${ }^{\circ}$ \\ Zonguldak Bülent Ecevit Üniversitesi, İlahiyat Fakültesi tarafından yayınlanmıştır. Tüm hakları saklıdır. \\ Published by Zonguldak Bulent Ecevit University, Faculty of Theology, Zonguldak, Turkey. All rights reserved.
}

Öz: Oryantalizm genelde Batılıların Doğu halklarının kültürünü özelde de islam kültürünü inceledikleri alanı ifade eden bir kavramdır. Oryantalistler, Batılı ilim adamIarının kendi dinî kaynaklarını incelemek için geliştirdikleri yöntemi, Islami kaynaklara da uygulama yolunu benimsemişlerdir. Bunların başında Yahudi asıllı Macar şarkiyatçı Ignaz Goldziher (1850-1921) gelmektedir. O, Batı'da hadisleri ilk defa sistemli bir şekilde tenkide tabi tutan kişidir. Goldziher "Muhammedanische Studien" isimli eserinin ikinci cildinde ağırlıklı olarak hadis konularına yer vermiş ve hadislerin tarihlendirilmesi hususunda metin eksenli bir yaklaşımı esas almıştır. O, bu eserinde, hadislerin isnadının varı-

\footnotetext{
* Bu makale çalışmasında, Ignaz Goldzıher'in 'Muhammedanische Studien I-II' eserlerinin 'İslam Kültürü Araştırmaları' ismi ile Otto Yayınları tarafından yapılan çevirisi esas alınmıştır. Kitabın 1. cildi Cihad Tunç tarafından tercüme, Mehmed Said Hatiboğlu tarafından da takdim edilmiştir. 2. cildin tercümesi ise Mehmed Said Hatiboğlu tarafından yapılmıştır.
} 
ğından söz etmekle beraber, hadislerin değerlendirilmesinde isnadı itibar edilir bir unsur olarak görmemiştir.

İslam kültürü üzerine yaptığı çok sayıdaki çalışmalarıyla Batı dünyasında meşhur olan Goldziher, kendinden sonra gelen Batılı araştırmacıların da bu konuda yolunu açmıştır. Ülkemiz başta olmak üzere İlam dünyasında, onun tarihselci yaklaşımı ve "Eski Ahid" tenkid metodunu esas alan çalışmaları bu alanda çalışan ilim adamlarının gündeminde olmuştur.

Goldziher'in hadisçiliği ve hadislere bakışı hakkında çok sayıda kitap ve makale çalışmasının yapıldığı malumdur. Özellikle Goldziher'in hadisler hakkındaki düşüncelerinin sağlıklı bir şekilde analiz edilebilmesi için onun Kur'ân ve Hz. Peygamber hakkındaki görüşleri dikkate alınarak hadisçiliğini konu edinen yeni bir makale çalışmasına ihtiyaç duyulmaktadır.

Sözü edilen amaca yönelik olarak, bu makale çalışmasında Goldziher'in "Muhammedanische Studien" isimli eseri bağlamında; Hz. Peygamber ve hadisler hakkındaki görüşlerinin kritiği yapılıp, daha sonraki dönemlerde elde ettiği eser ve veriler çerçevesinde, kaleme aldığı makaleleri doğrultusunda, yeni tespit ve görüşlerindeki birtakım değişiklerin neler olduğu gibi hususlar ele alınacaktır. Ayrıca onun hadis ve sünnet hakkındaki görüş değişikliklerinin mahiyetine vurgu yapılacaktır.

Anahtar Kelimeler: Goldziher, Hz. Peygamber, Hadis, İslam Kültürü, Kritik.

Abstract: Orientalism is a concept that refers to the area in which Westerners study the culture of Eastern people in general and Islamic culture in particular. Orientalists have adopted the method, which is developed by Western scholars to analyze their own religious sources, to analyze the Islamic sources, as well. As a Jewish-origin Hungarian Orientalist Ignaz Goldziher (1850-1921) is one of the leading names. He is the first to systematically criticize hadiths in the West. In the second volume of his work "Muhammedanische Studien", Goldziher mainly focused on hadith subjects and took a text-based approach in dating hadiths. Although he mentions the existence of attribution/isnad of hadiths in this work, he does not see attribution as a credible element in the evaluation of hadiths. Goldziher who is famous in the Western world with his numerous studies on Islamic culture, paved the way for Western researchers who came after him. In the Islamic world, especially in our country, his historicist approach and his works based on the "Old Testament" criticism method have been on the agenda of scholars working in this field.

It is known that many books and articles have been published about Goldziher's Studies on Hadith and his view of Hadith. Especially in order to analyze Goldziher's thoughts about hadiths in a healthy way, a new article on his approach to hadith is needed, taking into account his views on the Qur'an and the Holy Prophet.

In this article, in line with the mentioned goal, in the context of Goldziher's work named "Muhammedanische Studien"; His views on the Prophet and hadiths will 
be criticized, and within the framework of the works and data he obtained in later periods, in line with the articles he wrote, the new findings and changes in his views will be discussed. In addition, the nature of his changes of opinion on hadith and sunnah will be emphasized.

Keywords: Goldziher, Prophet, Hadith, Islamic Culture, Critical.

\section{Giriş}

Oryantalistlerin İslam araştırmalarına, miladi XII. yüzyıldan itibaren başladığı bilinen bir durumdur. Bu yüzyıldan itibaren İslam'ın entelektüel bir çerçevede inceleme gayreti başlamış, ilk aşamada Kur'an tercüme edilmiştir. ${ }^{1}$ Bunu takip eden süreçlerde de özellikle 13. ve 14. yüzyıllarda, İslamî kaynakların anlaşıımasına yönelik Arapça öğrenmek için üniversitelerde dil okullarının açılmasına önem verilmiştir. ${ }^{2}$ Başlangıçta Hristiyanlığı yaymak için vasıta olarak kullanılan oryantalizmin, daha sonraları özellikle Avrupa ülkelerinin siyasi, iktisadi, askeri, fikri ve kültürel politikalarına hizmet eder bir hal aldığını söylemek mümkündür. Oryantalist çalışmaların akademik tatminin ötesinde özellikle ekonomik yayılmacılık ve sömürgecilik döneminde İslam dünyasını daha yakından tanıyarak bu coğrafyada yürütülecek faaliyetler hakkında malzeme sağlamak gibi bir amacının olduğu da göz önünde bulundurulmadır. Hangi amaca yönelik olursa olsun oryantalizmin temsilcilerinin büyük çoğunluğunun Yahudi veya Hristiyan din adamları olduğu aşikârdır. Sözü edilen amaçlar çerçevesinde hadis alanına ilginin artmasına öncülük edenlerin başında ise Goldziher gelmektedir. ${ }^{4}$

Yahudi kökenli bir Macar olan Goldziher önceleri mensubu olduğu din üzerinde reform yapmak istemiş ve bu amaca yönelik olarak küçük yaşlardan itibaren eserler yazmaya başlamıştır. Mensubu olduğu dinî çevrede bu düşüncelerini gerçekleştirebileceği uygun bir ortam bulamaması nedeni ile o, İslami alandaki çaIışmalara yönelmiştir. Onu İslam araştırmalarına iten etkenlerden birinin de kendi toplumunun hâkim olduğu dar görüşlülüğün olduğu söylenebilir. ${ }^{5}$ Goldziher her yönü ile çok iyi yetişmiş bir şahsiyettir. Onun Avrupa'daki eğitimi ve araştırmalarından, Ortadoğu'daki eğitimi ve araştırmalarına kadar yaptığı ilmi faaliyetler göz önünde bulundurulduğunda bu durum, kendini şüpheye mahal bırakmadan ortaya koymaktadır. ${ }^{6}$

1 Bekir Kuzudişli, “Oryantalizm ve Hadisle İlgilenen Bazı Oryantalistler,, İstanbul Üniversitesi Illahiyat Fakültesi Dergisi, 7 (2012).

2 İbrahim Sarıçam vd., Ingiliz ve Alman Oryantalistlerin Hz. Muhammed Tasavvuru (Ankara: Nobel Yayınarı, 2011 ), 2. H. Musa Bağcı, Hadis Usulü ve Tarihi (Ankara: Bilay Yayınları, 2018), 435.

Hüseyin Akgün, Goldziher ve Hadis (Ankara: Araştırma Yayınlar, 2019), 11.

Akgün, Goldziher ve Hadis, 302.

Akgün, Goldziher ve Hadis, 40-50. 
İslam üzerine çok sayıda kitap ve makale kaleme alan Goldziher, Batı dünyasında kendisinden sonra gelen araştırmacılar için de önemli bir eşik kabul edilmiştir.7 Ayrıca o, Türkiye'de ve İslam dünyasında İslam kültürü üzerine yaptığı çalışmalar ile gündemde olmuş ve onunla ilgili olarak leh ve aleyhte görüşler ortaya konulmuştur. Bu makale çalışmasının temel konusunun, Goldziher'in genelde İslam kültürü özelde de hadis alanında yapmış olduğu araştırmalara bütün ayrıntıları ile girmek olmadığını ifade etmekte yarar vardır. Sözü edilen sahalarda işin uzmanlarınca yeterli araştırma ve tetkiklerin yapıldığı ortadadır.

\section{Goldziher Nezdinde İslami Kaynaklar ve Genellemeci Yaklaşım Metodolojisi}

Bu başlık altında ana hatları ile Goldziher'in başta Hz. Peygamber olmak üzere dinin temel kaynağı olan Kur'an ve hadislerin onun yanında nasıl bir değere sahip olduğu konusuna işaret edilecektir. Ayrıca onun sıkça kullandığı genellemeci yaklaşımla kafasında oluşturmuş olduğu metodolojinin nasıl bir sonuç ortaya çıkardığına dair bazı görüş ve değerlendirmelere yer verilecektir.

\subsection{Goldziher'in İslam'ın Temel Kaynaklarına Bakışı}

Goldziher'in İslam araştırmalarındaki donanımı ve çok sayıda kitap ve makale kaleme alması takdire şayan bir husustur. Onun matbu eserlerin sınırlı olduğu zaman diliminde el yazmaları üzerinden her türlü zorluğa katlanarak söz konusu kitap ve makaleleri yazmış olması ve kendi ifadesi ile İslam kültür araştırmalarına katkısı bir hakkı teslim etmek adına önemli bir husustur. Ancak İslam hakkında araştırma yapan bir kimsenin, dinin olmazsa olmaz temellerini hiçe sayarak hareket etmesi, o dinin mensuplarının duygu dünyasında nasıl ve ne şekilde hissedildiği de önemli bir durumdur. Goldziher'in İslam, Hz. Peygamber ve hadisler hakkındaki kanaatlerini göz ardı ederek, tamamen onun hadis merkezli İslam kültürü çalışmalarının büyüsü ile hareket etmek bizleri birtakım yanlışlara götürebilir.

Goldziher'in 'Muhammedanische Studien' isimli eseri bağlamında Hz. Peygamber ve hadisler hakkındaki görüşlerini kritik etmeden önce, eserlerindeki düşünceleri esas alınarak, onun hakkında ülkemizde yapılan çalışmalar çerçevesinde kendisine yöneltilen eleştirileri ana hatları ile hatırlamakta yarar vardır. Ancak onun İslam kültürü ve hadis anlayışını konu edinen makalelerin hepsinin ayrıntılarına burada yer vermemizin mümkün olmadığını da hatırlatmak

7 Bu konuda ayrıntılı bilgi için bk. Ignaz Goldziher, Hadis Kültürü Araştırmaları, ed. Hüseyin Akgün (Ankara: Otto Yayınları, 2020). 
Ignaz Goldziher'in ‘'̇slam Kültürü ve Araştırmaları I-II’ Eseri Bağlamında Hz. Peygamber ve Hadisler Hakkındaki Görüşlerine Yeniden Bakış

isteriz. ${ }^{8}$ Elbette onunla ilgili eleştirilerin temel çıkış noktası millî ya da dinî mensubiyeti ile ilgili olmamalıdır. Böyle bir anlayışın insaf ve ilmi davranmaktan çok uzak olduğu malumdur.

Goldziher'in hadis ve İslam kültürü ile ilgili görüşlerini ihtiva eden kitap ve makaleleri göz önüne alındığında Kur'an, Hz. Peygamber/nübüvvet ve İslam'ın mevcut durumunun onun için ne ifade ettiği gibi hususlardaki aşırı görüşleri, yapmış olduğu ilmi çalışmaları gölgede bırakmaktadır. Konuyu belirlenen sınırları dışına taşırmamak amacıyla ve bu konuda yapılan çalışmaların hacmi de göz önünde bulundurularak meseleye ana hatları ile temas edilecektir. ${ }^{9}$

Goldziher'in Kur'an hakkındaki temel düşüncesini şu şekilde özetlemek mümkündür: Ona göre Kur'an Hz. Peygamber'e ait bir kitap olup, onun görüşleri mesabesindedir. İslam Hz. Peygamber'in yaşadığı dönemde kemale ermiş bir din olmayıp, Kur'an da sonraki dönem Müslümanlarının katkıları ile ortaya çıkan bir bütün olup, İslam'ın kaynağı olma bakımından sınırlı bir yapıya sahiptir. Goldziher'e göre Kur'an bir yasa kitabı olmaktan ziyade, bir ibadet kitabıdır. Ayrıca o, iniş döneminde Kur'an kadar yalpalayan ve güven vermeyen hiçbir kitabın olmadığını iddia etmektedir. Ona göre, başından itibaren Müslümanların üzerine anlaşma sağladığı ortak bir Kur'an metni de yoktur. ${ }^{10}$ Ülkemiz âlimlerinden M. Said Hatiboğlu'nun okuyucularına, Goldziher'i okurken, atalarının dini Yahudiliğe samimiyetle bağlı, fakat Siyonist olmayan bir âlim karşısında olduklarını unutmamaları gerektiği ve onun Kur'an hakkındaki kanaatini göz önünde bulundurma yönünde tavsiyeleri vardır. ${ }^{11}$ Goldziher'in bu düşüncelerinden Kur'an'ın ilahi bir kitap olmadığı, Hz. Peygamber'in sözleri seviyesinde bir yere sahip olduğu anlaşılmaktadır.

Goldziher'in Hz. Peygamber ve nübüvvet hakkındaki düşünceleri ise Kur'an'a bakışından farklı değildir. Onun Hz. Peygamber hakkındaki görüşlerini kendi

8 Dilek Tekin, “Batılı Araştırmacıların Hadislerin Yazıı-Şifahi' Rivayeti Meselesine Bakışları”, Karadeniz Teknik Üniversitesi Illahiyat Fakültesi Dergisi 2/1 (2015); Fatma Kızıl, “Goldziher'den Schacht' a Oryantalist Literatürde Hadis ve Sünnet: Bir Okulun Yaşayan Geleneği", Hadis Tetkikleri Dergisi 7/2 (2009); Mutlu Gül vd., "Hadis IIlmine Dair Kaleme Alınan Almanca Akademik Çalışmalar", Ihya Uluslararası İslam Araştırmaları Dergisi 6/1 (2020); Hüseyin Akgün, "Hadislerin Otantikliği Hususunda Bazı Oryantalistlerin Görüşleri ve'Hadisin Özü' (Kern, Core) Kavramı", Hikmet Yurdu Düşünce-Yorum Sosyal Bilimler Araştırma Dergisi 8/8 (2015); i Ibrahim Hatiboğlu, "Yakın Doğu Seyahati ve Eserler Bağlamında Ignaz Goldziher ve İslâm Dünyası ile Fikri Etkileşimi", Marife 2/3 2002; Nimetullah Akın, "Hadislerin Yazılı Kaydı ve Literatür Esaslı Bir Disiplin Olma Süreci: A. Sprenger, I. Goldziher ve G. Schoeler'in Yaklaşımları", Hadis Tetkikleri Dergisi, 6/1 (2008).

9 bk. Süleyman Doğanay, Oryantalistlerin Hadisleri Tarihlendirme Yaklaşımları (İstanbul: Marmara Üniversitesi İlahiyat Fakültesi Yayınları, 2013); İbrahim Hatiboğlu, Çağdaşlaşma ve Hadis Tartışmaları (İstanbul: İz Yayıncılık, 2012), 56.

10 bk. Akgün, Goldziher ve Hadis, 302. (Goldziher Kur'an hakkındaki görüşlerine şu şekilde devam etmektedir: İslami kapsamlı bir şekilde tanımlarken, Kur'an'a büyük bir anlam izafe etmek veya İslam hakkındaki hükümleri sadece ve öncelikle Muhammed ümmetinin bu kutsal kitabına dayandırmak ciddi bir hata olacaktır. ... (Vorlesungen, 27'den naklen); Ignaz Goldzıher, Muhammedanische Studien 'Íslam Kültürü Araştırmaları, çev. Cihad Tunç (Otto Yayınları, 2019), 1/28.

11 Ignaz Goldzıher, Muhammedanische Studien 'İslam Kültürü Araştırmaları, çev. Cihad Tunç (Otto Yayınları, 2019), $1 / 28$. 
ifadeleri çerçevesinde "...Medine'de birkaç dindar mürit tarafından kabul görmüş Mekkeli hayalperestin yaptığı davetin çöle ilk nüfuz ettiği sıralarda onlardan göreceği tavrın ne olabileceği tahayyül edilsin..."12 ve "...Muhammed'in akidesinin, kendisini kavminin Peygamberi olmaya muktedir kılan dehanın ortaya koyduğu orijinal fikirlerin sadece kendisinde bulunuyor olması ile değil de, istisnasız olarak Yahudilik ve Hristiyanlıkta da bulunuyor olması, kültür tarihi açısından pek az ehemmiyeti haiz olabilir. Onun orijinalliğini teşkil eden husus, bu akidenin Arap dünya görüşüne zıt olarak, ilk önce Muhammed tarafından ortaya konulmuş olmasındadır..."13 şeklinde özetlemek mümkündür. Goldziher eserinin başka bir yerinde Hz. Peygamber'e gönderilen dine Allah'ın dini tabiri kullanmak yerine "...Muhammed'in dini..." şeklinde bir nitelemeyi tercih etmiştir. ${ }^{14} \mathrm{O} \mathrm{Hz}$. Peygamber'i bir din kurucusu olarak gördüğünü ise şu ifadeler ile dile getirmektedir: "...İslam'ın kendi kurucusunun söz ve fiillerinin toplandığı kaynaklara dayanarak-Peygamber'in bizatihi kendisinin demek yerine-Müslüman kilisesinin en eski akidesinin bilgilerine ulaşmak zorunda kalmanın, pek kötü bir durum olduğunu tekrar ifade etmemiz gerekmektedir..."15 Bu örnekler çerçevesinde dahi Goldziher'in, Hz. Peygamber'e gönderilen vahyin ilahi yönünü yok sayarak, orijinal bir tarafının olmadığı, Yahudilik ve Hristiyanlıktan devşirilme bir yapıya sahip olduğu vurgusunu yaptığı anlaşılmaktadır.

Genelde İslam'ın, özelde de Kur'an ve Hz. Peygamber'e gönderilen vahyin mevcut durumu Goldziher için ne ifade ettiği meselesi önemlidir. Anlaşıldığına göre onun için Kur'an ayetleri, Hz. Peygamber'in yirmi üç yıllık vahiy sürecinde kendi sözlerini ifade eden ondan sonraki dönem için de kültürel olarak var olan ancak evrensel anlamda da Yahudilik ve Hristiyanlık gibi bir dine temel referans niteliği olmayan dini metinlerdir. Diğer bir ifade ile kültürel değeri olan dinî metinlerdir. O bir meseleyi kendi metodolojisine göre açıklamaya çalışırken ayetlere bir kültür malzemesi olarak yer vermektedir. Örneğin o, cahiliye dönemi insanlarının öç almada aynı ile mukabele etme durumunu açıklarken ayetlere yer vererek meseleyi açıklamaya çalışır. ${ }^{16}$ Bununla ilgili olarak eserinde yer verdiği birkaç ayeti örnek olarak zikretmekte yarar vardır. "Onlar bollukta da darlıkta da Allah yolunda harcarlar, öfkelerini yenerler, insanları affederler. Allah işini güzel yapanları sever."17 , "Onlar çirkin bir şey yaptıkları veya kendilerine kötülük ettikleri zaman Allah'ı hatırlarlar da hemen günahlarının bağışlanmasını dilerler. Zaten günahları Allah'tan başka kim bağışlayabilir ki? Onlar, yaptıklarında bile bile ısrar etmezler. ${ }^{\prime 18}$ Goldziher her ne kadar ayetlere ilahi değer vererek bakmasa da bir kültür malzemesi olarak eserin bütününde bu yöntemi kullanmaktadır.

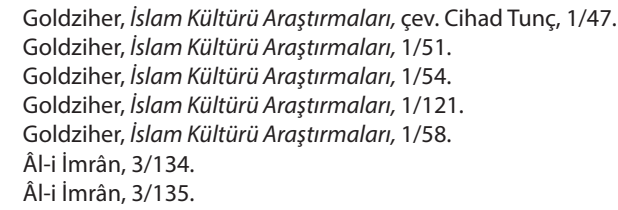


Hadislerin çok az bir bölümünün $\mathrm{Hz}$. Peygamber'e ait olabileceğini ifade eden Goldziher, diğer büyük bölümünün ise daha sonraki süreçlerde hadis formunda ortaya çıktığını kabul etmektedir. ${ }^{19} \mathrm{O}$ bu yaklaşımı ile bir kültür malzemesi olarak ister temel hadis kaynaklarındaki, ister mevzu rivayet veya dini sahada yer alan eserlerdeki bütün malzemeyi eşdeğer gören bir tarzı esas almıştır. Goldziher, ilk dönemde belli kesimlerin şiir meselesine ne şekilde yaklaştıklarını açıklarken "Bir kimsenin vücudunun irinle dolu olması, şiirle dolu olmasından daha hayırlıdır."20 rivayetini örnek vermektedir. O ayetleri kullanmada gösterdiği rahatlığı hiçbir ayrım yapmadan ister hadis kaynakları isterse de başka kaynaklar olsun, malzeme farkı ve kaynak değeri gözetmeksizin aynı değeri vermiştir. ${ }^{21}$

Goldziher'den İslam'a inansın veya en azından Müslümanların ilk asırdan bu yana göz önünde bulundurduğu Kur'an başta olmak üzere kaynak hiyerarşisine uyarak bir konuyu izah etsin gibi bir beklenti içerisinde değiliz. Ancak onun, özellikle İslam araştırmaları ile ilgili çalışmalarına bakıldığı zaman, ayet ve hadisleri kullanmasının yanında, İslami açıdan temel referans olamayacak her türlü kaynağı ve bilgiyi sahih ve itibar edilir anlayışı ile kullanmaktan da geri durmadığı görülmektedir. Burada dikkat çekmek istediğimiz husus onun nasıl bir yöntem ve anlayışla İslami kaynaklara yaklaştığını ana hatları ile tekrar hatırlatmak ve bu yolla elde edilen bilginin sıhhati ile ilgili zihinlere bir soru işareti koymaktır.

\section{2. Goldziher'in Genellemeci Yaklaşımına Karşı Bazı Görüşler}

Goldziher'in sınırlı sayıda kaynaklar üzerinden ve el yazmalarını kullanarak İslam kültürü üzerine araştırmalar yapmasının takdire şayan olduğu daha önceki satırlarda ifade edilmişti. Kendisi bir metodoloji çerçevesinde kaleme aldığı yazılarında İslam'a karşı saygılı bir dil kullandığı kanaati dahi uyandırmıştır. Acaba onun bundan yaklaşık 120 sene önce yaptığı ilmî çalışmalarında düştüğü ilmi yanlışlıklar, sadece içinde bulunduğu kaynak yetmezliğine bağlanabilir mi? ${ }^{22}$ Elbette Müslüman ilahiyatçıların bu alanda çalışanlarının, onun kaynak yetersizliğine bağlı eksikliğinden kaynaklanan yanlışlıklarını düzeltmek görevi olduğu gibi, aynı zamanda İslam araştırmaları sahasındaki çabalarını takdir etmek gibi hem ahlaki hem de ilmi bir görevi vardır. Hatta Goldziher'in yaşadığı dönemde Ma'mer'in Câmî, Abdurrazzak'ın ve İbn Ebî Şeybe'nin Musannaf'ları, Taberî́nin Mu'cem'leri ve bu sahada çok sayıda kaynağı görememiş olması buna ilave edilirse bu daha da elzem hâle gelmektedir. ${ }^{23} \mathrm{O}$, hadis ve sünnet konusunu belli bir tarih felsefesine göre ele alıp değerlendirmiş, rivayetleri İslam ümmetinin doğuşu ve dönüşümünü analizde birer materyal olarak incelemiş ve bunu yaparken de Yahudi geleneği, efsane araştırmaları, dinler tarihi çalışmaları

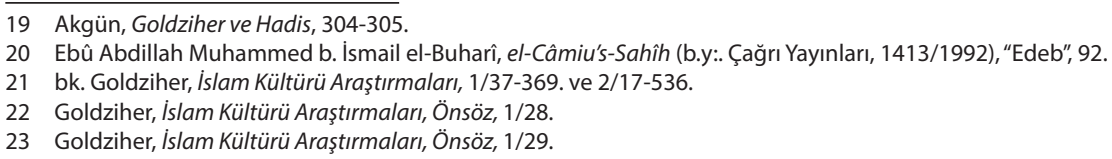


ve tarihî filolojik metodunu kullanmıştır. Ayrıca o tarihselci yaklaşımı ve Eski Ahid tenkit metodunu hadis çalışmalarına uygulamıştır. ${ }^{24}$

Goldziher'e yapılan eleştirilerin temelini, onun alandaki bütün kaynaklara ulaşamamasından ortaya çıkan yanlışlıklar değil, tam aksine sözü edilen metodundaki genellemeci ve aşırı şüpheci tavrı oluşturmaktadır. ${ }^{25}$ Örneğin Goldziher, lisan bilgisine çok fazla güvenmesi sebebi ile meslektaşlarının yapmış olduğu hataları düzeltmekte, ancak kendisi de bazı kavramların ne anlama geldiği hususunda birtakım hatalar yapabilmektedir. Ayrıca onun İslami kaynaklardaki ibareleri yüzeysel ve gördüğü şekilde değerlendirmesi sonucu, feci olarak nitelenebilecek hatalar yaptığı da örnekleri ile zikredilmektedir. ${ }^{26}$ Bunun dışında Goldziher, Hatiboğlu'nun örnekleriyle sunduğu kitap ve kaynaklara ulaşma sorunu dışında, tamamen hadislerin tespitine yönelik zihniyet sorunu ile meseleye yaklaştığı izlenimi vermektedir. O bir incelemesinde başta sahabeler olmak üzere hadis rivayetini çok ciddiye alanlar olduğunu, noksanlık ve fazlalık yaparım korkusu ile Hz. Peygamber'den duyulan sözleri rivayet etmekten çekindiklerini zikretmektedir. Bu tespitte bir sorun yoktur. Ancak Goldziher bu çekingenliğin ve titizliğin başka bir sebebi olarak da Hz. Ömer'den örnek vererek, hadisin bilinmesinin istenmemesi olduğunu iddia etmektedir. Onun dayandığı kaynakta dahi bu meselenin ileri sürüldüğü gibi olmadığı görülmektedir. Bunun ise ön yargıya dayalı bir yalan olduğunu söylemek mümkündür. ${ }^{27}$ Buna göre Batı dünyasında İslam araştırmalarıyla önemli yer işgal eden bir şahsiyetin, kendi zihin dünyasına ışık tutacak bir tenkit yolu izlediği anlaşılmaktadır. ${ }^{28}$

\section{Goldziher'in 'İslam Kültürü Araştırmaları’ Eseri Bağlamında Hadis ve Sünnet}

Goldziher'in özellikle 'İslam Kültür Araştırmaları 1' eseri incelendiğinde, 'Mürüvvet ve Din'29, 'Arap Kabileciliği ve İslam'30, 'Arap ve Acem'31, 'Şuûbiyye'32 ve 'Şuûbiyye ve İlmî Yeri'33 gibi hususları içeren konulara temas ettiği görülür. Ayrıca o, ekler ve notlar bölümünde ise 'Cahiliyye'den Ne Anlaşılmalıdır?'34, 'Müşriklik ve İslam'da Mevtaya Ta'zim Meselesi'35, 'Cahiliyye ve İslam Lisanı'36, 'Künye'nin

24 Mehmet Emin Özafşar, Oryantalist Yaklaşıma İtirazlar (Ankara: Otto Yayınları, 2015), 28.

25 Akgün, Goldziher ve Hadis, 305. Bk. Hıdır, Özcan, "Oryantalizme Karşı Oksidentalizm: Hadis Oksidentalizmi-M. Fuad Sezgin ve M. Mustafa A'zami Örneği-, Hadis Tetkikleri Dergisi, 5/1 (2007).

26 bk. Mehmed S. Hatiboğlu, "Batı'daki Hadis Çalışmaları Üzerine”, İslami Araştırmalar 6/2 (1992): 108.

27 Mehmed S. Hatiboğlu, "Batı'daki Hadis Çalışmaları Üzerine”, 109.

28 Talat Koçyiğit, "I. Goldziher'in Hadisle Illgili Bazı Görüşlerinin Tahlil ve Tenkidi", Ankara Üniversitesi Illahiyat Fakültesi Dergisi 15 (1967): 55.

29 Goldziher, İlam Kültürü Araştırmaları, 1/37-84.

30 Goldziher, İslam Kültürü Araştırmaları, 1/85-159.

31 Goldziher, İlam Kültürü Araştırmaları, 1/161-216.

32 Goldziher, İlam Kültürü Araştırmaları, 1/217-252.

33 Goldziher, Islam Kültürü Araştırmaları, 1/253-300.

34 Goldziher, İlam Kültürü Araştırmaları, 1/303-314.

35 Goldziher, İslam Kültürü Araştırmaları, 1/315-357.

36 Goldziher, Islam Kültürü Araştırmaları, 1/359-362. 
Şeref İzharı Olarak Kullanılışı'37, 'Siyah ve Beyazlar'38, 'Türklere Dair Hadisler'39 ve 'Arapça Şiir Yazmış İranlılar'40 gibi konu başlıklarına yer vermektedir. Bu başlıklar içerisinde kısmen Hz. Peygamber ve risalet konularına temas edilenler olsa da, genel ve ağırlıklı olarak İslam tarihi, kelamî meseleler, mezhepler tarihi, fıkıh, tasavvuf ve kültürel konuların ağırlığı dikkat çekmektedir. Malum olduğu üzere Goldziher, hadis ve sünnet meselelerine 'İslam Kültür Araştırmaları 2' kitabında yer vermiştir. Onun hadis ve sünnete dair temel görüşlerinin tespiti, kitabında takip ettiği konu başlıkları sırasına uygun olarak yapılacaktır.

\subsection{Goldziher'in Hadis ve Sünnete Dair Görüşleri}

Goldziher hadis kelimesinin 'rivayet, hikâye' anlamına geldiğini, Taberî (ö. 310/923) Belâzûrî (ö. 279/892-93) gibi tarih, Tayâlisî (ö. 204/819) ve Muslim (ö. 261/875) gibi hadis kaynakları üzerinden örnekleri ile açıkladıktan sonra ${ }^{41} \mathrm{~Hz}$. Peygamber'den sonraki dönemde hadis rivayetinin mahiyetini şu ifadeleri ile dile getirmektedir.

“Peygamber'in muttaki müritleri, onun irad ettiği talimi sözleri üstada istinaden tam bir ihtimamla nakletmiş bulunmaktadır. ...Peygamber'in vefatından sonra, onun zihniyetine göre ifade edilmiş olarak gördükleri veya yüksek kurtarıcı vasıfta buldukları talimi mahiyette pek çok sözü kendiliklerinden onlara katmışlardır. Bununla beraber bunları ona isnad etmekte herhangi bir endişeye kapıldıkları da yoktu..."42

Goldziher'in bu ifadelerinde, Hz. Peygamber'den sonraki dönemde neredeyse herkesin her alanda hadis uydurduğu düşüncesi hâkimdir. Onun hadisler hakkındaki şüpheyi genel bir usul haline getirdiğini, onun şu ifadelerinden anlamak mümkündür.

“...Hadislerin engin külliyatıyla olan devamlı ilişki o kadar ihtimamla tasnif olunmuş kitaplardaki yığılı malzeme hakkında bizi iyimser bir itimattan ziyade, şüphe ile dolu bir temkine götürecektir. Hatta rivayetlerin büyük bir kısmına karşı Dozy'nin (1820-1883)'nin beslemekte olduğu güvene biz pek ulaşabilecek değiliz. ..."43

Goldziher'in hadislerde şüpheyi önceleyen genel bakışını yansıtan ifadeleri yukarıda zikredilenler ile sınırlı değildir. O rivayetleri İslam'ın gençlik devri tarihinin birer vesikası olarak görmemektedir. Ona göre rivayetler bu dinin geçirdiği

\footnotetext{
Goldziher, İslam Kültürü Araştırmaları, 1/363-364.

Goldziher, İslam Kültürü Araştırmaları, 1/365-366.

Goldziher, İslam Kültürü Araştırmaları, 1/367-368.

Goldziher, İslam Kültürü Araştırmaları, 1/369.

41 Goldziher, Islam Kültürü Araştırmaları, çev. Mehmed Said Hatiboğlu (11-372. sayfalar); Cihad Tunç (373-536. sayfalar) 2/17-19.

42 Goldziher, İslam Kültürü Araştırmaları, 2/19.

43 Goldziher, Islam Kültürü Araştırmaları, 2/20.
} 
inkişafın daha ileriki devrelerinde ümmet içinde ortaya çıkmış temayüllerin birer şahididir. ${ }^{44}$ Goldziher hadis hakkındaki bu mülahazalarından sonra bir hadisin sened ve metinden meydana geldiğini dile getirmektedir. O metin kelimesinin bu anlamda ilk defa kullanılmadığını, eski Araplar tarafından da bu tür bir kullanımın olduğuna işaret etmektedir. ${ }^{45}$ İslam'ı din olarak kabul etmeyen Goldziher'in, bu anlamda her şeyi eski dönmeler ile irtibatlandırma psikolojisi ile hareket ettiği söylenebilir.

Hadislerin yazılı ve şifahi olarak rivayeti konusuna değinen Goldziher, İslam'ın ilk onlu seneleri zarfında yazı ile muhafaza edilmiş oldukları bildirilen hadislerin en eski rivayetleri oluşturduklarını kabul ettiğini söylemektedir. Ona göre Hz. Peygamber'in sözlerini idame ettirme arzusu nasıl olurda şifahi rivayetin eline bırakılabilir? ${ }^{46}$ Hadislerin ilk dönemden itibaren tamamının yazılı olarak gelmesi gerektiği düşüncesi, hadis tarihine ve mevcut hadis usulüne tamamen zıt bir yaklaşımdır. ${ }^{47}$

Hadis ve sünnet kelimelerinin birbirinden ayrılması gerektiğini söyleyen Goldziher hadisi, Hz. Peygamber'e isnad edilen şifahi beyan, sünneti ise dinî veya hukukî bir hususla ilgili Müslüman cemaatinde cari olan âdet olarak kabul etmektedir. Ona göre bir sünnetin bir hadise dayanması ve onu teyit etmesine gerek yoktur. Bu düşüncelerini ise temel kaynaklar ile desteklemektedir. Ancak bu temellendirmelerini yaparken sadece hadis kaynaklarını esas almayıp, İslam kültür ve medeniyet alanındaki bütün kaynakları fark gözetmeksizin tezini ispat için kullanmaktadır. ${ }^{48}$

İslam'ın farklı bir din olduğunu baştan kabul etmeyen ve dinî bir geleneğinin olmasının mümkün olmadığı düşüncesi ile hareket eden Goldziher, toplumların bazı hususlarda birbirlerinin ortak dil ve kavramlarına sahip olabileceği gerçeğini dikkate almadan ${ }^{49}$ sünnet mefhumunu müşriklere dayandırmak yolu ile hadis ve sünnete dair bakış açısını ortaya koymaktadır. O İslamî sünnet kavramını eski Arap uygulamalarının bir devamı ve Arap telakkisinin tadil edilmiş bir şekli olarak kabul etmekle ${ }^{50}$ aslında dinî olarak yeni bir şey olmadığını söylemek istemektedir.

\subsection{Emeviler ve Abbasiler Döneminde Hadis ve Sünnet}

Goldziher İslam dünyasında dinî hayatın, ilk adımlarından itibaren sünnete bağlı temeller üzerine kurulu bulunduğuna inanmanın temelsiz bir görüş

\footnotetext{
Goldziher, İslam Kültürü Araştırmaları, 2/20.

Goldziher, İlam Kültürü Araştırmaları, 2/22.

Goldziher, İslam Kültürü Araştırmaları, 2/24.

47 bk. Talat Koçyiğit, Hadis Tarihi (Anakara: Ankara Üniversitesi Illahiyat Fakültesi Yayınları, 1998), 26-67; Ahmet Yücel, Hadis Tarihi (İstanbul: Marmara Üniversitesi Illahiyat Fakültesi Yayınları, 2011), 40-42.

48 bk. Goldziher, İslam Kültürü Araştırmaları, 2/27-28.

49 Toplumsal etkileşim ve kimlik inşası konusunda bk. Süleyman İlhan, "Akışkan Toplumda Kimlik İnşası: Geçişken, Eklektik, Ben Odaklı Kimlikler", Fırat Üniversitesi Sosyal Bilimler Dergisi 23/2 (2013).

50 bk. Goldziher, İslam Kültürü Araştırmaları, 2/29-30.
} 
olduğunu söylemektedir. $\mathrm{O}$, böyle bir hayatın başlangıçtan beri dinle fazlaca meşgul olunan ve hukuk ve hayatla ilgili teşriî unsurların, daha sonraki zamanda sünnet olarak tasdik görecek bir çeşit âdet ortaya çıkardığı Medine'de kurulabildiğini ifade etmektedir. ${ }^{51}$ Her ne kadar başlangıçta İslam coğrafyasının her tarafında Medine'de olduğu gibi sünnete bağlı temeller hâkim olmasa da onun, sünnetin birtakım âdetlerinin daha sonraki dönemlerde dinî hayatta bu hale dönüştüğü iddiası gerçeği yansıtmaktan uzaktır. Ayrıca o, Kur'an ve Hz. Peygamber misyonunu her zaman yaptığı gibi dikkate almama gayreti içinde hareket etmektedir. Bu durum onun, toplumlardaki sosyal ve siyasal gelişmelere söz konusu İslam olunca itibar etmemesinin de bir göstergesidir. Malum olduğu üzere İslam'ın sabitleri ve değişkenleri vardır. Elbette daha sonraki dönemlerde, Hz. Peygamber'in 23 yıllık peygamberlik hayatındaki uygulamalarının en iyi bilindiği ya da ibadetlerin nasıl yapılacağı konularında Medinelilerin bilgisine başvurmayı bir eksiklik olarak görmek, sağlıklı bir bakış açısını yansıtmamaktadır.

Hz. Peygamber'in vefatından sonraki dönemde hadislerin naklinde sahabe ve tabiinin önemine işaret eden Goldziher, sahabe ve tabiinin gerekli malzemeyi kendinden sonraki nesle teslim ettiğini de ifade eder. Ona göre birtakım 'gayyur' kimseler, kendilerine şeriatın kapalı kalan noktalarını aydınlatacak sahabe ve tabiin bulmak amacı ile Müslüman dünyasının daha uzak bölgelerine seyahatlere çıktığını dile getirir. ${ }^{52}$ Bütün bu çabaları 'fî talebi'l-ilm'53 ilim aramak için yapılan seyahatler olarak ifade eden Goldziher, genellemeci bir yaklaşımla, Peygamber'e atfedilmiş sözlerin yeni naşirleri olarak nitelendirmektedir. O, ilim arama çabaları sonucunda yeni mahsullerin ortaya çıktığını, mütedeyyin kimselerin makbul gördükleri hususları Hz. Peygamber'e ulaşan bir sened ilavesi ile meşrulaştırma yoluna gittiklerini iddia etmektedir. Ona göre artık bu iş, sahabe hayatta olmadığı için de çok kolaydı. İslami akideleri yayarak, o dönemin dinsizlik cereyanlarının ortadan kalkacağını düşünen 'dindar hadis imalcileri' bunu Hz. Peygamber'e isnad ediyorlardı. ${ }^{54}$ Müslümanlarca oluşturulan hadis usulüne göre dahi bazı konularda değişik nedenler ile hadis uydurularak bunların Hz. Peygamber'e isnad edildiğini söylemek mümkündür. ${ }^{55}$ Ancak Goldziher genel bakış açısına uygun olarak hiçbir ayırım yapmaksızın bütün dindarların her zaman, konu ayırt etmeden hadis uydurdukları şüphesi ile hareket etmektedir.

Emevî döneminin önemli halifesi olan II. Ömer'in hadislerin tedvinine yönelik gayret ve hassasiyeti Goldziher'in dikkatinden kaçmış değildir. Onu ilk asır ilahiyatçılarının sessiz çalışmalarına ameli bir katkı sağlayan kimse olarak nitelemiştir. Ayrıca o, Ömer b. Abdilaziz'in zamanında sünnetin resmi bir

51 Goldziher, İslam Kültürü Araştırmaları, 2/49.

52 Goldziher, İslam Kültürü Araştırmaları, 2/55.

53 Koçyiğit, Hadis Tarihi, 97-103.

54 Goldziher, İslam Kültürü Araştırmaları, 2/56.

55 bk. Mehmet Yaşar Kandemir, Mevzû Hadisler Menşei Tanıma Yolları Tenkidi (Ankara: Diyanet İşleri Başkanlığı Yayınları, 1991). 
hüviyet kazandığını ve halifenin sünneti hükümdarlığının en uzak eyaletlerinde geçerli kılma gayreti içerisinde olduğunu ifade etmektedir. II. Ömer'in valiliklere gönderdiği emirnamede sünneti ihya etmek ve bidatin kökünü kazımak düşüncesi de vardı. Il. Ömer'in hilafetinden sonra idareye muhalif kimselerin hadis uydurma faaliyetlerini 'hadis tarlası' olarak niteleyen Goldziher, buna karşın iktidarın da bu yolu kullandığını iddia etmektedir. ${ }^{56}$ Ona göre bütün bunların sonunda birbiri ile siyasi ve akidevi çekişme içerisinde olan gruplar şaşalı ve müessir isnatlarla bütün konularda hadis uydurmuşlardır. ${ }^{57}$ Onun ifadelerinden nerede ise 'hadis' kavramı altına giren her şeyin uydurulduğu şüphesine kapılmak mümkündür.

Hadislerin tedvin aşamasında önemli rol üstenen Zuhrî (50-124/670-742)'nin Hz. Peygamber'e isnad ederek bir uydurma icat ve neşr ettiğini iddia eden Goldziher, bu itham ve iddiasında tarihi gerçeklerle çelişmektedir. ${ }^{58}$ Dağınık halde bulunan hadislerin bir araya getirilmesi gayretinin başındaki Zuhrî, Goldziher tarafından haksız eleştiri ve töhmetlere maruz kalmakladır. Zuhrî kendisine yazılı gelen defterleri kabul ediyor, böylece her rivayet onun nezdinde meşru hale geliyordu. Ona göre Zuhrî Emevî sülalesinin menfaatlerine hizmet eden bir kimse olup, iktidar çevrelerinden gelen baskılara boyun eğiyordu. ${ }^{59}$ Ayrıca Goldziher Zuhrî'yi iktidarla geçici uzlaşmada olmayı arzulayan çevrelerin adamı olarak da nitelendirmekte, onu saraya sık sık uğramaktan çekinmeyen, hükümdarların meclislerinde bulunmaktan hiçbir şekilde sakınmayan bir kimse olarak görmektedir. ${ }^{60}$ Goldziher'in bize anlattığı Zuhrî, hadis olmayan malzemeleri kendi süzgecinden geçirerek onları güvenilir hadisler hâline getirip iktidarın görüş ve direktifleri doğrultusunda hareket etmektedir.

İslam Tarihi üzerine yoğunlaşan araştırmaları ile tanınan Alman müsteşrik Josef Horovitz (1874-1931), Goldziher'in Zuhrî́nin halifelerin teveccühüne mazhar olmak için onların lehine hadis uydurduğu şeklindeki değerlendirmesine katılmamaktadır. ${ }^{61}$ Horovitz, kaleme almış olduğu Zuhrî başlığında onu, ön yargıdan ve genellemeci yaklaşımdan uzak bütün yönleri ile objektif bir şekilde tanıtmaya çalışmaktadır.62 Örneğin o, ez-Zehebî'den (ö. 748/1348) yaptığı nakiller ile Zuhrî'nin olağan üstü hafızasının, rivayetleri toplamaya olan bitmez tükenmez azmine yardım ettiği bilgisine yer vermektedir. Ayrıca o, Zuhrî́nin yanında levhalar ve sayfalar ile dolaştığı, duyduğu şeyleri yazdığı bilgisine de işaret etmektedir. ${ }^{63}$ Horovitz bu bakış açısı ile Goldziher'in Zuhrî şahsında hadis meselelerine ne kadar subjektif yaklaştığını ortaya koymaktadır.

\footnotetext{
Goldziher, İslam Kültürü Araştırmaları, 2/57.

Goldziher, İslam Kültürü Araştırmaları, 2/58.

Goldziher, İslam Kültürü Araştırmaları, 2/59. Bu hususta bk. Hatiboğlu'nun dipnot açıklaması.

Goldziher, İlam Kültürü Araştırmaları, 2/62.

Goldziher, İslam Kültürü Araştırmaları, 2/63.

Josef Horovıtz, İslami Tarihçiliğin Doğuşu, çev. Ramazan Özmen vd., (Ankara: Ankara Okulu Yayınları, 2019), 10-11.

Horovitz, İslami Tarihçiliğin Doğuşu, 132-153.

Horovitz, İslami Tarihçiliğin Doğuşu, 147.
} 
Goldziher'e göre Emevîler dönemi, hadislerin resmî tahrifi demektir. O, bu dönemde hadislerin küçük hesaplara hizmet ettiğini de iddia etmektedir. ${ }^{64}$ Daha sonraki satırlarında o, "...Bu gaye ile imal edilmiş rivayetlerin şüphesiz büyük bir kısmı resmî teşebbüs ve tazyik sayesinde vücut bulmuştur." değerlendirmesi ile bu döneme dair genel kanaatini ortaya koymaktadır. Ona göre kasti düşünce sadece hadislerin tertibinde değil, muhalif fırkaların delillerini ortadan kaldırmak için de kullanılmaktaydı. ${ }^{65}$

Goldziher, Abbasî sülalesinin iktidara geçişi ile sünnet kültürünün, ilim ve hayat rehberi sıfatı ile resmi bir hâl aldığını dile getirir. O Emeviler döneminde Medinelilerin ve onların taraftarlarının çileli günlerinin Abbasîler ile sona erdiği değerlendirmesini yapmaktadır. ${ }^{66}$ Abbasî döneminde hadisin Emevilere göre daha çok uygulama alanı bulduğuna dikkat çeken Goldziher, yeni dönemde hadisin bir hürriyet havası içerisinde tetkikinin geliştiğini dile getirir. ${ }^{67}$

Goldziher, ilk nesillerin hazırlayıcı çalışmalarının Müslüman teşriinin bir sistem haline getirilmesine temel vazifesi göremeyecek derecede zayıf olduğunu iddia etmektedir. Ona göre aynı bölge içerisinde dahi bir mesele hakkında sabit ve kati kaide mevcut değildi. ${ }^{68}$ Goldziher'in bu meselede de ön yargılı ve genelleyici tavrı kendisini göstermektedir. Daha önce de ifade edildiği gibi İslam'ın temel ve değişken ilkeleri göz ardı edilerek meselelere bakıldığı zaman bu tür değerlendirmeler yapılarak bir din hakkında bu denli ön yargı ve şüphe dolu düşünceler ortaya koymak mümkündür. Ayrıca İslam'ın temel değerleri baki kalmak kaydı ile insan ihtiyaçları esasına dayalı dinî alanın genişliği sonucu ortaya çıkan yeni yorumların yapılmasını, dinî argümanların eksikliği olarak algılamak yerine o dinin mensuplarına tanınan yeni meselelere çözüm bulma ruhsatı olarak görmek daha da makul olabilir.

Goldziher hadislerin hayatın bütün meselelerini çözme gücüne sahip olmadığı düşüncesini vurguladıktan sonra, bazı kimselerin hadisleri yeterli delil olarak görmemesi sonucu Ehl-i Rey'in ortaya çıktığı görüşüne yer verir. $\mathrm{O}$, hadislerin yeni kurulacak hukukun temeli olamayacağını ve bunun için ise âlemşümul yayılma kudreti Müslüman dünyasına kadar serbestçe uzanmış bulunan Roma hukukunun teşriî mevzuatının çoğunlukla iktibas edildiğini dile getirir. ${ }^{69}$ Görüldüğü üzere Goldziher'e göre hadis, kendi coğrafyasındaki hukuka dahi delillik yapabilecek nitelikte olmayıp, bu açığı kapatmak için de İslam mensuplarının imdadına Roma hukuku yetişerek sorun çözülmüş olacaktır.

64 Goldziher, İlam Kültürü Araştırmaları, 2/65.

65 Goldziher, İslam Kültürü Araştırmaları, 2/70-71.

66 Goldziher, İslam Kültürü Araştırmaları, 2/103.

67 Goldziher, İslam Kültürü Araştırmaları, 2/104-105.

68 Goldziher, İslam Kültürü Araştırmaları, 2/107.

69 Goldziher, İslam Kültürü Araştırmaları, 2/108. 
Bir meselenin ne denli bu kadar çarpıtılabileceğinin en açık örneklerini Goldziher'de de görmek mümkündür. Örneğin o, Ashabu'l-Hadis'in derlenen hadislerin sıhhat dereceleri ve ravilerin kusursuzlukları üzerine o zamanlar pek fazla eğilmediklerini söylemektedir. İsnad ricalinin sıkı tenkitten geçirilmesi ise; daha sonraları hadislerin tahrif edilme kolaylığı, Sünni ilahiyatçılar tarafından yasaklanmış dini ve içtimaı her türlü eğilimleri desteklemeye elverişli hâle geldiğinin görülmesi ile başlamıştır. Böylece hadisin dış şekli korumaya alınmış ve Ashabu'l-Hadis'teki endişe ortadan kaldırılmıştır. ${ }^{70}$ Hadislerin menşeini ve yayılma tarzını tetkikte daha itinalı davrananların ise Irak'taki Ashab'r-Rey olduğunu söyleyen Goldziher, reycilerin kendilerine sunulan hukukî meselelerin çözümünde hadislere hiç de ihtiyaç duymadıklarını iddia etmektedir. Buna mukabil Ashab'l-Hadis'in ise her meseleyi hadise dayandırarak çözdüğünü bunu yaparken de hadis imalatına başvurduklarını dile getirmektedir. ${ }^{71}$ Ashabu'l-Hadis ile Ashabu'r-Rey'i bu denli farklı göstererek, birinin hadis kullanmadan hiçbir meseleyi çözemediğini ve bunu da yaparken hadis uydurduğunu, diğerinin ise neredeyse içtihatlarında hadise başvurmadığını iddia eden Goldziher'in isnat ve metin tenkidi hakkındaki görüşleri bir tarafa, genellemeci ve realite ile çelişen tavrı burada da müşahede edilmektedir. ${ }^{72}$

Goldziher'in Hz. Peygamber takıntısı Ashabu'l-Hadis ve Ashabu'r-Rey meselesini izah ederken de devam devam etmektedir. Onun ifadesine göre Müslüman halk nazarında Ashab'l-Hadis'in akidesi, dinin gerçek bir kabulü olmuş, inançlı bir müminin gözünde her kanunun, Kitabın otoritesine veya 'Müslüman otoritenin en üstün şairi' olarak nitelendirdiği Peygamber'in otoritesine dayanması lüzumlu hâle gelmiştir. Rey'ciler de daha sonraki dönemlerde kendilerini bu duruma uydurmak zorunda kalmışlardır. ${ }^{73}$

İslam'da başlangıçtan itibaren tek bir sünnetten bahsedilemeyeceğini dile getiren Goldziher, aynı konuda birbirine zıt mekteplerin görüşlerini desteklemeye matuf birbirinden farklı ve çeşitli rivayetlerin aynı derecede makbul olduğuna işaret etmektedir. O, mevcut zıtlıkların 'tercih' gibi değişik yöntemler ile giderilmeye çalışıldığını dile getirmektedir. ${ }^{74}$

Goldziher sünnetin Abbasiler döneminde kazandığı hamle, âlemi sünnetçilerin! keyfine teslim edilmemişti değerlendirmesini yapmaktadır. O 'hadis imalatının' muttaki muhaddislerce devam ettiğine de tekrar vurgu yapmaktadır. ${ }^{75}$

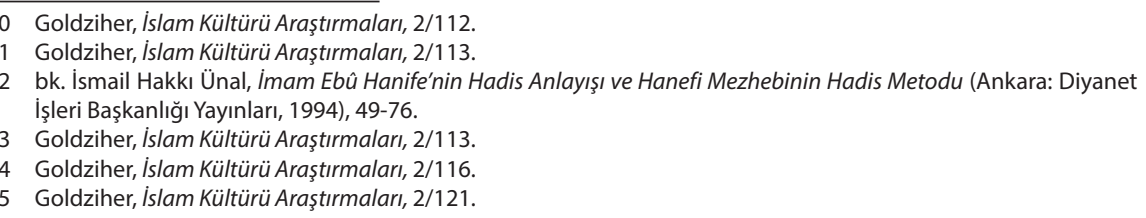




\section{3. İslam'da Fırka Kavgaları ve Hadis}

Allah tarafından son din olarak gönderilen İslam, Hz. Peygamber'in uygulamaları ile bir nizam hâline gelmiştir. O çevresinde bulunanlardan başlamak üzere insanlara hak ve hukukun ne olduğunu öğretmiş, topluma sulh ve sükûn getirme gayreti içerisinde olmuştur. Ancak $\mathrm{Hz}$. Peygamber'in vefatından sonraki dönemlerde henüz çeyrek asır geçmeden, belli gruplar arasında siyasi mücadele kendini göstermiş hatta bunun silahlı bir şekle dönüştüğü zamanlar da olmuştur. ${ }^{76}$ Ne yazık ki İslam ümmetinde meydana gelmiş özellikle siyasi, fikri ve içtimai her türlü önemli olayın müspet ya da menfi şekiller altında hadislerle ifade edildiği de bilinen bir husus hâline gelmiştir. ${ }^{77}$ Her ne kadar bütün meseleler için bir genelleme yapmak doğru bir yaklaşım olmasa da klasik hadis usulü kitaplarında yer alan ve bu hususta da mahir! olduğu anlaşılan bir bidatçinin "Biz bir işi benimsetmek istediğimiz zaman, onu hadis hâline getirirdik." ${ }^{178}$ sözü o dönemin sosyal ortamı hakkında bizlere bir ip ucu vermektedir.

Goldziher'e göre medeniyet tarihi bakımından hadisin en ilgi çekici tarafı, onun teşri sahası ile ilgili olmayıp, hadisin en önemli taraflarının İslam'ın içinde bulunduğu siyasi durum ve şartlar karşısında Müslüman dünyanın dinî unsurlarının nasıl hareket etmiş olduğunu gösteren yönüdür. Ona göre dinî çevrelerin bütün akideleri gibi siyasi hüviyetteki kanaatleri de hadis kılığına bürünmüş durumdadır. ${ }^{79} \mathrm{O}$ siyasi hadislerin ortaya çıkma meselesi ile ilgili görüşlerini şu şekilde dile getirmektedir: İster devlet düzenini koruma endişesi ile isterse de İslam'ın bütünlüğünün temini gereği, yöneticiler liyakatsiz de olsa iktidarı ellerinde bulunduran kimselere itaat etmek gerekir. Bunu sağlamaya yönelik olarak da her durumda itaat görüşünü hararetle tavsiye eden hadisler ile yönetime ve idarecilere hizmette bulunmuşlardır. ${ }^{80} \mathrm{Her}$ ne kadar Goldziher'in iddia ettiği gibi siyasi ve yönetimle ilgili hadislerin tamamının mevcut durumu meşrulaştırmak için imal edildiği düşüncesi gerçeği yansıtmasa da siyasi konularda ve özellikle de itaat mevzuundaki hadisler arasında uydurma olabilecek rivayetlerin varlığı inkâr götürmeyecek bir durumdur. ${ }^{81}$

Zalim idareye kayıtsız şartsız itaat etmek, beğenilmeyen ve hoşlanılmayan idarecilere başkaldırmamak ve bu işi sadece Allah'a bırakmanın gerekliliği ile ilgili çok sayıda hadis uydurulduğuna dair örnekler veren Goldziher, daha sonraki dönemlerde meydana gelen siyasi olayların rivayetler yolu ile meşru hâle getirilme gayretlerinden söz etmektedir. ${ }^{82}$ Hatta bu işin Abbasoğullarının $\mathrm{Hz}$.

76 Mehmed Said Hatiboğlu, Siyasi-Ictimai Hadiselerle Hadis Münasebetleri (Ankara: Otto Yayınları, 2015$), 21$.

77 Hatiboğlu, Siyasi-lçtimai Hadiselerle Hadis Münasebetleri, 14. bk. Sadık Cihan, Uydurma Hadislerin Doğuşu Siyasi ve Sosyo-Politik Olaylarla Ilgisi (Samsun: Kardeşler Ofset, 1996).

78 Hatîb el-Bağdâdî, Kitâbu'l-Kifâye fî ilmi'r-rivaye (Haydarabâd: Dâiretu'l-Meârif Usmaniyye, 1357), 123.

79 Goldziher, İslam Kültürü Araştırmaları, 2/125.

80 Goldziher, İslam Kültürü Araştırmaları, 2/130-131.

81 bk. İlyas Canikli, Hadislere Göre Yöneticilere İtaatin Sınırları (Ankara: İlahiyat Yayınları, 2004).

82 bk. Goldziher, İslam Kültürü Araştırmaları, 2/132-150. 
Peygamber'e övdürülmesine kadar gittiği açıkça ortadadır. ${ }^{83}$ Ayrıca Goldziher Şia'nın, Hz. Ali'nin vasiyet yolu ile halifeliğe layık olduğunu ispata yönelik olarak fırka hadislerinin icadına işaret ettikten sonra ${ }^{84}$ buna yönelik o, Şia'nın delil olarak ileri sürdüğü rivayetlerden örnekler vermektedir. ${ }^{85}$ Hadis imal etme faaliyetlerinin Şia ve ona muhalif olan gruplarca karşılıklı devam ettiğine işaret eden Goldziher, konu sünnet/hadis olmasına rağmen tezini delillendirmek için hadis kaynakları dışındaki eserlerde yer alan ve hadise kaynaklık etmesi söz konusu olmayan siyasi rivayetler üzerinden genellemeci bir tarz ile hadislerin geneli hakkında ayırt etmeden yargıya varma yolunu burada da kullanmaktadır. ${ }^{86}$

Goldziher'in kendi usulüne göre siyasi rivayetler üzerinden hadisler hakkında genel bir kanaate varması birçok yönden eleştiriye açık bir durumdur. Ancak Goldziher'in burada zikrettiği örnekler dışında da siyasi alanla ilgili fırkaların kendi davalarının haklılığını ispata yönelik rivayetler uydurduğu gerçeğini göz ardı etmemek gerekir.

\subsection{Hadis Uydurulması ve Buna Yönelik Tepkiler}

Hadis kaynakları dışındaki her türlü dinî literatürü hadisin kaynağı olarak görüp burada yer alan haberleri esas alarak neredeyse bütün hadislere şüphe ile bakan Goldziher, İslam hayatındaki her akımın ve buna muhalif olan kesimlerin hangi alan olursa olsun görüşlerini hadisleştirerek dile getirdiklerini ifade etmektedir. ${ }^{87}$ Ona göre hadis uyduranlara karşı da farklı yöntemler ile karşı konulmaya çalışıımıştır. Bunlardan biri halisane niyet ile uydurmalara karşı yeni uydurmalar devriye sokularak mücadele edilmeye çalışılmıştır. O bu düşüncesini değişik örnekler ile destekleme yoluna gitmiştir. ${ }^{88}$ Hadis uydurulmasına yönelik olarak hadisçiler muhitinde hadis tenkidinin başlamış olduğu düşüncesi Goldziher tarafından dile getirilmiştir. ${ }^{89}$

Hadis uydurulmasına karşı tedbir olarak isnadın devreye sokulması da bir tepki olarak ortaya konulmuş, bu çerçevede ravilerin mükemmelliğine dikkat edilmiştir..$^{90} \mathrm{Bu}$ bağlamda rical tenkidi ${ }^{91}$ uydurmaların önünü kesmek için başvurulan yollardan biri olmuştur. ${ }^{92}$ İsnadda yer alan ravilerin cerh edilmesi

83 Ebû İsâ Muhammed b. İsa et-Tirmizî, es-Sunen, thk. İbrahim Adve Avz (b.y.: Çağrı Yayınları, 1413/1992), "Menâkib", 28 (No: 3758). Tizmizî bu hadisin hasen olduğunun söylemektedir. Zikredilen hadisi takiben Hz. Peygamber'den "Abbas bendendir. Ben de ondanım." rivayeti Tirmizî'de yer almaktadır. bk. Tirmizî, "Menâkib", 28 (No. 3759)

84 Goldziher, İslam Kültürü Araştırmaları, 2/161.

85 bk. Goldziher, İslam Kültürü Araştırmaları, 2/162-165.

86 bk. Goldziher, İslam Kültürü Araştırmaları, 2/164-182.

87 Goldziher, İslam Kültürü Araştırmaları, 2/183.

88 Goldziher, İslam Kültürü Araştırmaları, 2/184.

89 Goldziher, İslam Kültürü Araştırmaları, 2/193.

90 Goldziher, İslam Kültürü Araştırmaları, 2/196.

91 Goldziher, İlam Kültürü Araştırmaları, 2/197.

92 Ebû'I-Hüseyn Müslim b. Haccâc Müslim, el-Câmıu's-Sahîh. (İstanbul: Çağrı Yayınları, y.y:. 1413/1992), “Mukaddi$\mathrm{me}^{\prime \prime}, 14,15$. 
de uydurmalara karşı alınan tedbirlerin en önemlilerinden kabul edilmiştir. ${ }^{93}$ Ancak bütün bunlara karşın hadis uyduranların uydurma isnadlar ve uydurma isimler ile faaliyetlerine devam ettiklerine işaret edilmektedir. ${ }^{94}$ Goldziher bazı şahsi tarafsızlık tezahürlerine rağmen, hadis tenkidinde göz önüne alınan bakış açılarının, önemli hadis malzemesinin bazı eklemelerden uzak tutulmasında sınırlı da olsa işe yaradığını dile getirmektedir. ${ }^{95} \mathrm{O}$, isnad şekil bakımından nizamî olduğu sürece Müslüman münekkitlerin en göze batan hatalara dahi sessiz kaldıklarını iddia etmektedir. ${ }^{96}$ Bütün bunlar sonucunda Goldziher, hadis tenkidine sübjektifliğin hâkim olması nedeni ile itimat konusunda birlikteliğin sağlanamadığını dile getirmektedir. ${ }^{97}$

Goldziher'in ifade etmiş olduğu ve hadis uyduranlara karşı alınan bazı önlemlerin, hadis tarihinde yer alan hususlara genel anlamda aykırı bir yönünün olmadığını söylemek mümkündür. ${ }^{98}$ Ancak onun, isnada çok şekli yaklaşıldığı ve hadis tenkidinin sadece münekkidin inisiyatifinde olduğu düşüncesine katılmak mümkün değildir. Elbette isnad ve hadis tenkidinde hiçbir şüphe yoktur demek mümkün değildir. Ancak hadis uyduranlara karşı alınan bunca önlemlerin çok azının faydası olduğu şüphesi sağlıklı bir yaklaşım olarak kabul edilemez.

\subsection{Goldziher'e Göre Ahlakı Yüceltme ve Eğlence Vasıtası Olarak Hadis}

Goldziher hadisleri ahlakı yüceltme ve bir eğlence vasıtası olarak görmektedir. O, her ne kadar hadis uyduranlara karşı hadise yapılan eklemeler ve isnadın sağlamlığı konusunda titiz davranılmış olunsa da hadisin bütün konuları üzerinde aynı titizliğin gösterilmediğini söylemektedir. Goldziher özellikle haram ve helal konularıyla ilgili olarak yani akidevi veya hukukî istidlallerin kaynakları olan hadisler konusunda hassas davranıldığını ve bu tür hadislerin bütün uydurma füruattan salim olmasının öneminin göz önünde bulundurulduğuna işaret etmektedir. Ayrıca o, pek çok ilahiyatçının hiçbir şer'i niteliğe sahip olmayan ve sadece dinî hikâyeler, terbiye ve ahlakı talimatı Peygamber namına nakletme adına çok da sıkı davranmadığını söylemektedir. Şer'i bir hadisin isnadında yer aldığında hadisi kullanılamaz hâle getiren rical, ahlaki bir hadis söz konusu olduğunda yeter derecede sika sayılıyordu. ${ }^{99} \mathrm{O}$, kendi batıl kuruntularına göre halkı iyiliğe

\footnotetext{
Goldziher, İslam Kültürü Araştırmaları, 2/199.

Goldziher, İslam Kültürü Araştırmaları, 2/202.

Goldziher, İlam Kültürü Araştırmaları, 2/204.

Goldziher, İlam Kültürü Araştırmaları, 2/206.

Goldziher, İslam Kültürü Araştırmaları, 2/209.

bk. Kandemir, Mevzû Hadisler Menşei Tanıma Yolları Tenkidi, 93-168.

99 Goldziher, İslam Kültürü Araştırmaları, 2/213-214. (Goldziher'in dile getirdiği husus bizim klasik hadis usulü eserlerinde yer almaktadır. Hatîb el-Bağdâdî, Ahmed b. Hanbel'den nakille şunları nakletmektedir. "Hz. Peygamber'den bize helal, haram, sünnetler ve hükümler konusunda bir şey rivayet edildiğinde isnad hususunda hassas davranırdık. Hz. Peygamber'den bize amellerin faziletleri, bir hüküm getirmeyen ya da bir hükmü kaldırmayan konularda rivayet edildiğinde ise isnadda gevşek davranırdık." (Hatîb el-Bağdâdî, Kitâbu'l-Kifâye fî ilmi'r-rivaye, 164).
} 
teşvik etmek için ${ }^{100}$ zahid kılığına bürünmüş birtakım cehele tarafından bu durumun kabullenildiğini dile getirmektedir. Goldziher'e göre bu gibi kimselerin hadis uydurma mazeretlerinin temelinde dinî hisleri kuvvetlendirmek ve Allah'tan korkmaya teşvik etmek vardı. ${ }^{101}$

Goldziher'e göre Peygamber'e isnad edilen birtakım dini sözlerde, Kur'an surelerinden her birinin faziletleri övülmekte ve onlar ile meşgul olan dindar kimselere açıkça mükâfatlar tayin edilmektedir. ${ }^{102} \mathrm{Bu}$ konuda klasik kaynaklarımızda Goldziher'in yapmış olduğu tespitlerin çok ötesinde malzeme bulmak mümkündür. ${ }^{103}$

Goldziher hadis edebiyatında Peygamber'e ref edilmiş çok sayıda rivayet olduğunu iddia etmektedir. Ona göre uzun zamanlar tedavülde olan mevkuf ve maktu sözler kolaylıkla Peygamber'e ref edilmiştir. ${ }^{104}$

Goldziher Hz. Peygamber'e ve hadislere karşı önyargısını şu yaklaşım ve zihniyeti ile sürdürmektedir. Ona göre Müşriklik döneminin müsait karşılanan hikemiyyatı Peygamber'e naklettirilmekten sakınılmamıştır. Goldziher hızını kesmeyip Muhammed'in de Kur'an'a Cahiliyye hikemiyyatını kattığını açıkça dile getirmektedir. ${ }^{105}$ Goldziher'in bu tavrına şaşırmamak gerekir. Daha önce onun Kur'an ve Hz. Peygamber hakkındaki görüşlerine temas edilmişti.

Goldziher'e göre Ahd-i Atik'in ve İncil'in hikemiyyatı ref usulü ile $\mathrm{Hz}$. Peygamber'in sözleri hâline getirilmiştir. Ona göre İslam ümmeti, menfaati gereği takvayı hâkim kılmak ve dini faziletlerin ifası ile şeriata bağlı kalınmasını teşvik etmek için Peygamber'den sözler icat edip bunları tedavüle çıkarmayı mubah saymak, hemen hemen müşterek bir kanaat hâline gelmiştir. ${ }^{106}$

Goldziher'e göre hadis uydurmak vicdani kaygıdan uzak hâle gelerek, saf ve basit takva hissine, psikolojik olarak pek yakın bir başka unsur karışmıştır. Bunlar ise; manevi eğlence, zekâ oyunudur. Buna misal olarak da "Halkı güldürmek gayesi ile yalan hadis rivayet edenin vay hâline, vay hâline, vay hâline."107 rivayetine yer vermektedir. ${ }^{108}$ Onun hadislerin geneli hakkındaki bu ve benzer yaklaşımına şaşırmamak gerekir. Kanaatimize göre o, Hz. Peygamber'den gelen hadis külliyatının hepsinin uydurma olduğu şüphesini oluşturmak gibi bir zihniyetle hareket etmektedir.

100 Goldziher, İslam Kültürü Araştırmaları, 2/215.

101 Nevevî, Şerhu Sahîhi Muslim, (Beyrut: İhyâu't-turâsi'l-Arabî, ts), 1/70.

102 Goldziher, İslam Kültürü Araştırmaları, 2/216-217.

103 bk. M. Hayri Kırbaşoğlu, Alternatif Hadis Metodolojisi (Ankara: Kitâbiyât, 2002), 345-347; Bayram Kanarya, Ihtilaflı Hadisler-Imam Şâfiì'nin Yaklaşımı (İstanbul: İz Yayıncılık, 2017), 187-191.

104 bk. Yusuf Suiçmez, Sahabe ve Tabiin Sözlerinin Hz. Peygamber'e Nispeti (Ankara: Otto Yayınları, 2015), 95-156.

105 Goldziher, İslam Kültürü Araştırmaları, 2/218.

106 Goldziher, İslam Kültürü Araştırmaları, 2/220.

107 Tirmizî, “Zühd", 10 (No: 2315); Ebû Davud, “Edeb”, 80 (No: 4990).

108 Goldziher, İlam Kültürü Araştırmaları, 2/221. 


\subsection{Goldziher'in Hadislerin Derlenmesi ile İlgili Görüşleri}

Goldziher ülkenin ilahiyatçılarının, hadisin kendi memleketlerinde arz ettiği boşluğu doldurmak istedikleri zaman, diğer ülkelerde neşredilmiş hadisleri tanıma fırsatı bulmak için seyahate çıktıklarını ifade etmektedir. Böylece hadisin isnadında bu seyahati yapan kimse son isim olarak yer alıyordu. Ona göre Irak âlimleri mukaddes topraklarda yaşayan muttaki zatların ağzından Hicazî rivayetleri işitmek amacı ile oralara yapılan hacdan seve seve istifade ediyorlardı. Hadisleri, bunları nakletmekte olan önemli şahısların ağzından veya onları kendilerinden almış olanlardan doğrudan doğruya derlemeye ve daha sonra da bunların hamileri olmaya çok önem veriliyordu. Bu hırsın tatmini için de birçok seyahate çıkılmıştır. ${ }^{109}$ 'Talebu'l-Hadis' için Goldziher'in verdiği bilgilerde genel anlamda bir sorun görülmese de onun bütün bu yoldaki çabaları 'bir hırsın tatmini' olarak nitelendirmesi makul karşılanacak bir durum değildir. Ayrıca onun, genel anlamda hadisleri toplama faaliyeti gösteren hadisçileri 'ticaretçi' olarak nitelemesini, bu çabaları şüpheli duruma getirme gayreti olarak görmek mümkündür. ${ }^{110}$

Goldziher hiçbir ayrım yapmadan hadis toplama gayretlerini hafife alan bir tarzla şu görüşleri dile getirmektedir. Ona göre hadis toplama müptelası olan kimseler her tarafı didik didik etmiş ve bütün bu faaliyetler kayıtsız şartsız spor menzilesine düşmüştür. Bu kimseler hadislerin muhtevasına bakmaksızın, bir şeref unvanı elde etmek ve o zamana kadar meçhul kalmış bazı sözlerin isnadında boy göstermek için uzun seyahatlere girişmiştir."11 Her ne kadar bu hususta art niyetli kimseler olsa da hadis toplama faaliyetlerini herkes için sadece 'bir şeref unvanı' elde etme çabası olarak görmek, bir nevi haksızlıktır. Örneğin meşhur sahabî Câbir b. Abdillah Buharî'de yer alan bir habere göre, Abdullah ibn Uneys'in elinde bulunan tek bir hadisi öğrenmek amacı ile bir aylık yolu gitmek zorunda kalmıştır. ${ }^{112}$

\subsection{Hadislerin Yazı İle Tespit Meselesi ve Hadis Edebiyatı}

Goldziher 'Kitabetu'I-Hadis' yani hadislerin yazıIması meselesi ile ilgili görüşler ileri sürmüştür. $\mathrm{O}$, temel İslami ve diğer kaynaklar çerçevesinde konuyu çeşitli yönleri ile ele alarak hadislerin yazı ile tespit edilmesi meselesinin iki noktada odaklandığı söylemiştir. Bunlardan birincisi "Kur'an dışında benden bir şey yazmayınız. Kim bir şey yazdı ise onu yok etsin."113 rivayeti ile dile getirilen ve ilk dönemde Kur'an ile hadislerin karışma endişesi ile yazımının yasaklanmasıdır. Karşı görüşte olanlar ise "ilmi kayıt edeyim mi"114 rivayeti ile hadis yazımının yasak

109 Goldziher, İslam Kültürü Araştırmaları, 2/244.

110 Goldziher, İlam Kültürü Araştırmaları, 2/251.

111 Goldziher, İslam Kültürü Araştırmaları, 2/253.

112 Buharî, "Ilm", 19.

113 Müslim, "Zühd", 16.

114 Hatîb Bağdâdî, Takyîdu'I-IIm. (Beyrut: Dâru ihya, 1974), 65. 
olmadığını söyleyenlerdir. Goldziher'e göre her iki grup da kendi görüşlerini Peygamber'e isnad edilen rivayetlere dayandırmıştır. ${ }^{115}$ Diğer bir ifade ile zikredilen deliller ona göre gruplar tarafından imal edilmiştir. ${ }^{116}$ Goldziher her iki düşünceye sahip olanlar arasında cereyan eden tartışmalar çerçevesinde konuyu irdelemeye çalışmaktadır.

Goldziher, İslam'da dini hayat üzerinde hâkimiyeti olan edebiyatın, ilk dönemde gelişimini dinî amillerin tayin etmediğini söylemektedir. ${ }^{117}$ Biz burada hadis alanı ile ilişkili olduğu düşünülen edebiyat meselesine değinmeyi öncelemekteyiz. Bu bağlamda Goldziher'in kelam ve fıkıh ilminin gelişimi noktasındaki değerlendirmesi onun her daim var olan genellemeci yaklaşım zihniyetini yansıtmaktadır. Ona göre sözü edilen ilimler, Peygamber'in hırkasına bürünmüş hükümdarların gölgesinde gelişmiştir. $\mathrm{O}$ Emevîlerin ilk dönemlerinde dinî rivayetin edebî nevi mertebesine yükseldiğini söylemektedir. ${ }^{118} \mathrm{O}$ hukuk edebiyatının hadis edebiyatından önce geldiği vurgusunu yaptıktan sonra, fıkıhçılar hadislerden yararlanmak istedikleri takdirde, gerek şifahi gerekse sahip oldukları defterlerden bizzat derledikleri ve öğrendikleri haberlere dayanarak hareket ettiklerini ifade etmektedir. ${ }^{119}$

Goldziher, hadis edebiyatının oluşması için toplanan hadis malzemelerini ise 'iki neslin hayal mahsulü' olarak nitelendirmektedir. Ayrıca o sünnet malzemesi ile 'Yahudi Mişnası' arasında benzerlik olduğuna dikkat çekmektedir. ${ }^{120}$ Onun İslami edebiyatın oluşumunun tamamının hükümdarların gölgesinde geliştiği şüphesi ile hareket etmesi ve bu edebiyatı iki neslin hayal mahsulü olarak nitelemesi dikkat çekicidir.

Goldziher Halife II. Ömer'in emri ile Zuhrî'nin hadisleri bir araya getirmedeki rolüne değinmiş ve ona göre böylece halifenin daha sonraki nesiller tarafından hayırla yâd edilmesi sağlanmıştır. ${ }^{121}$ Hadislerin tedvininden sonraki süreçte Mâlik'in (ö. 179/795) Muvattâ'sı ortaya çıkmıştır. Ona göre Mâlik Muvattâ isimli eseri ile her ne kadar mütehassıs için, usûl-i hadis sahasında temel bir öneme sahip olsa da aslî anlamda bir hadis musannifi değildir. ${ }^{122}$

'Tasnîfu'l-Hadis' hadislerin konularına göre sınıflandırılması meselesi Goldziher nazarında önemli bir merhaledir. Çünkü ona göre biriken hadis malzemelerinin konularına göre ayrılması kullanım açısından önemli bir kolaylık sağlamaktaydı. Bu çerçevede bir hadisin mükemmel olmasının şartı ise sahih

115 Goldziher, İlam Kültürü Araştırmaları, 2/272.

116 Goldziher, İslam Kültürü Araştırmaları, 2/273.

117 Goldziher, İslam Kültürü Araştırmaları, 2/280.

118 Goldziher, İslam Kültürü Araştırmaları, 2/285.

119 Goldziher, İslam Kültürü Araştırmaları, 2/286.

120 Goldziher, İslam Kültürü Araştırmaları, 2/287.

121 bk. Goldziher, İslam Kültürü Araştırmaları, 2/289-290.

122 Goldziher, İlam Kültürü Araştırmaları, 2/299. 
ve kesintisiz halkalar ile sahabeye dayanmasıdır ki buna da 'irsâl' denir. ${ }^{123} \mathrm{Bu}$ dönemde 'Musned' ve 'Musannef' olarak isimlendirilen eserler ortaya çıkmıştır. Makalenin hududu göz önüne alındığında burada fazla tarihi isimlendirme ve ayrıntıya girme imkânı da yoktur. Sonuçta Goldziher klasik 'Hadis Usulü Tarihi' bilgileri çerçevesinde 'Musned' ve 'Musannef' türü hadis kitapları hakkında kendi bakış açısına göre çeşitli değerlendirmeler yapmıştır. ${ }^{124}$

Goldziher Ahmed b. Hanbel (ö. 241/855)'in Musned'i ile ilgili kanaatlerini dile getirdikten sonra ${ }^{125}$ Buhârî (ö. 256/870)'nin Sahihi hakkında da şu değerlendirmeyi yapmaktadır. $\mathrm{O}$, sadece kendisine hem sika hem de yeterli derecede sahih görünenlerden bir kitap meydana getirmek arzusu ile hareket etmemiş, aynı zamanda kendi dinî görüşünü paylaşanların güttükleri amelî gayelere hizmet edecek bir el kitabı takdim etmek arzusu içerisinde olmuştur. ${ }^{126}$ Ona göre Buhârî her şeyden önce kendi malzemesinin hangi teolojik fikre bir fayda sağlayıp sağlayamayacağını düşünmüştür. ${ }^{127}$

Goldziher Muslim (ö. 261/875)'in hadis eseri hakkında da ana hatları ile şu değerlendirmeyi yapmaktadır. Muslim'in te'lifinde çeşitli bablar hiçbir başıı taşımamaktadır. O da muasırı gibi eseri ile fıkha hizmet etmeyi amaçlamıştır. Fakat derlenmiş hadis malzemesinden kendince gerçeğe en mükemmel cevabı veriyor görünen neticeleri çıkarma himmetini okuyucuya bırakmıştır. Muslim, daha önce kullanılmış malzemeyi yeniden ele almadan, birbirleri ile ilgili rivayetleri bir arada tasnif etmektedir. ${ }^{128}$ Neticede her iki sahih edebiyat, öncelikle isnad tenkidinde gösterilecek titizliği temsil etmektedir. ${ }^{129}$ Ayrıca ona göre iki sahihin şartları arasında, bir hadisin hüccet niteliğine sahip olabilmesi için isnadda yer alan ricalin 'sika' vasfına sahip olması gerekir. ${ }^{130}$ Buraya kadar yer verilen hadis kitapları hakkında Goldziher o günün malzemesi çerçevesinde bu ve benzer nitelemeler yaparak hadis kitapları hakkındaki kanaatini dile getirmektedir.

Goldziher hadis edebiyatı konusu çerçevesinde Ebû Davud (ö. 275/888), Tirmizî (ö. 279/892), Nesâî (ö. 304/916), İbn Mâce (ö. 273/887) ve Dârîmî (ö. 255/869)'nin eserleri hakkında da çeşitli değerlendirmeler yapmıştır. ${ }^{131}$

\subsection{Goldziher'e Göre Hadis ve Ahd-i Cedîd (İncil) İlişkisi}

İnsanlık âlemi, farklı dinlere ve kültüre sahip olsalar da bilinçli olarak ya da olmayarak birbirlerini bilgi ve kültür birikimleri ile etkileyebilir. Hatta onların

\footnotetext{
123 Goldziher, İslam Kültürü Araştırmaları, 2/308-309.

124 bk. Goldziher, Islam Kültürü Araştırmaları, 2/315-316.

125 Goldziher, İslam Kültürü Araştırmaları, 2/311.

126 Goldziher, İlam Kültürü Araştırmaları, 2/323.

127 Goldziher, Islam Kültürü Araştırmaları, 2/324.

128 Goldziher, İslam Kültürü Araştırmaları, 2/334.

129 Goldziher, İlam Kültürü Araştırmaları, 2/335.

130 Goldziher, İslam Kültürü Araştırmaları, 2/336.

131 bk. Goldziher, Islam Kültürü Araştırmaları, 2/338-368.
} 
hayatlarını düzenleyen gerek dinî ve gerekse kültürel birikimlerden zararı olmayan ve kendilerince yararlı görmüş oldukları hususları da kendi hayatlarına taşıdıkları bilinen bir husustur. ${ }^{132}$ Ancak Goldziher meseleye, İslam'ın yetersizliği tezi üzerinden bir zihniyet ile yaklaşmaktadır. Ona göre İslam dini kabul ettiği bazı hususları dahi önceki dinlerden alarak kendine mal etmiştir. ${ }^{133} \mathrm{O}$, dinlerin ve kültürlerin doğru kabul ettikleri konuları, insanların kendi hayatlarına taşımalarını bir süreç olarak görmek yerine, 'Íncil'den alınan iktibas' tabiri ile meseleyi izah yolunu seçmekte ve burada yer vermediğimiz bazı örnekler ile tezini desteklemektedir. ${ }^{134} \mathrm{Bu}$ konuda Goldziher, 'İslam'ın başlangıçta İncil unsurlarının etkisinde kaldığını iyice öğrenmiş bulunmaktayız.'135 demektedir. Ayrıca Goldziher İslam'ın aslında yeni bir din olmadığını ispata yönelik, Aristo'nun 'tavassut' doktrininden çıkan ve Kur'an ayetlerine de dayanan İslam ahlak akidesi ile Yahudilik ve Hristiyanlık arasındaki münasebete dikkat çekmektedir. ${ }^{136}$

\section{Goldziher'in Hadis ve Sünnet ile İlgili Görüşlerindeki Değişiklikler}

Goldziher'in Muhammedanische Studien adlı eserinden sonra elde ettiği İslamî eser ve veriler doğrultusunda, bazı yeni tespitlerinin olduğu ve bunlar doğrultusunda hadis ile ilgili görüşlerinde birtakım değiş̧ikliklerin meydana geldiği zikredilmektedir. ${ }^{137}$ Ancak bu değişikliklerin Goldziher'in hadis ve sünnet ile ilgili temel düşünceleri ile mi ilgili olduğu ya da ulaşmış olduğu yeni kaynak veriler ile bazı konuların izahına yönelik mi olduğu önemlidir. Hatırlanacak olursa o, Kur'an'ın Hz. Peygamber'in sözü mesabesinde olduğunu, hadislerin ise çok azı dışında daha sonraki dönemlerde imal edilerek Peygamber'e isnad edildiğini veya Yahudi ve Hristiyan kültüründen beslendiğini iddia etmektedir. Sonuçta o, İslam'ı bir din değil de bir kültür olarak kabul etmektedir. Onun hadis ve sünnet hakkındaki düşüncelerinde meydana gelen değişiklikleri değerlendirmek için bu hususların göz önünde bulundurulması önemli bir yere sahiptir.

Bu alandaki çalışmaları ile tanınan Hüseyin Akgün, editörlüğünü yaptığı ve Goldziher'in daha sonraki dönemlerde kaleme aldığı beş makaleden oluşan "Hadis Kültürü Araştırmaları" kitabına yazdığı girişte, Goldziher'in hadislerin tedvin ve tasnif tarihini öne çektiğini, Musned'in belli bir mezhebi önceleyen kitap olmadığını ve hadislerin daha sahabe döneminde yazıldığını kabul ettiğini söylemektedir. ${ }^{138}$

\footnotetext{
132 Kültürlerarası iletişim hakkında İlker Özdemir, "Kültürlerarası İletişimin Önemi", Uluslararası Kıbrıs Üniversitesi Folklar/Edebiyat Dergisi 17/66 (2011).

133 bk. Goldziher, İlam Kültürü Araştırmaları, 2/501.

134 bk. Goldziher, İslam Kültürü Araştırmaları, 2/506-514.

135 Goldziher, İslam Kültürü Araştırmaları, 2/515.

136 Goldziher, İslam Kültürü Araştırmaları, 2/520.

137 Goldziher, İslam Kültürü Araştırmaları, 15.

138 Hüseyin Akgün'ün editör olarak, Goldziher'in beş makalesinden oluşan ve İslam Kültürü Araştırmaları ismi basılan kitaba yazdığı giriş, 17.
} 
Goldziher'in 'Hadis Kültüründe Yer Alan İncil Parçaları'139 adı ile Türkçe'ye çevrilen makalesinde, daha önce zikredilen görüşlerine benzer Peygamber'in Matta'yı alıp kendi tarzında açıkladığı iddiası devam etmektedir. Ayrıca hadis literatürü dışındaki İslami kaynaklarda yer alan sıhhati tartışmalı rivayetlerden hareketle İncil ile ilişkilendirmeler yapılarak sanki bunlar Hz. Peygamber'den nakledilen sahih rivayetlermiş gibi bir algı ile hareket edildiği müşahede edilmektedir. ${ }^{140}$

'Hadis'te Yeni Eflatuncu ve Gnostik Unsurlar' ismi ile Türkçe'ye tercüme edilen makalesinde Goldziher, daha önce iddia etmiş olduğu hadis olarak rivayet edilmiş malzemenin içerisinde Yeni Eflatuncu ve gnostik öğelerin olduğu görüşüne daha sonra kaleme aldığı makalesinde de devam etmektedir. O bu çerçevede 'İslam'ın tipik kendine mal etme tutkusu...' tabiri ile hadisin kaynağı hakkında genellemeci bir yaklaşım ile şüpheci tavrını sürdürmektedir. ${ }^{141} \mathrm{Bu}$ konudaki iddialarını daha çok hadis kaynağı olmayan dinî literatür üzerinden delillendirmektedir. ${ }^{142}$

Anladığımız kadarı ile Goldziher'in daha sonra kaleme aldığı makalelerinde, sözü edilen görüşlerinin Hz. Peygamber'in hadislerine genel anlamdaki şüpheci bakışını değiştirmeye yönelik olmadığı, yeni hadis malzemeleri ile yazdıklarını bir nevi tashih etme gayreti içerisinde olduğunu söylemek mümkündür.

\section{Sonuç}

Goldziher Kur'an'ı Hz. Peygamber'in sözü olarak kabul etmekte ve hadislerin çok azı dışındakileri daha sonraki dönemde imal edilerek Peygamber'e isnat edildiğini söylemektedir. Dolayısı ile onun nazarında İslam'ın bir din olması söz konusu olmadığı gibi, dinin temel kaynaklarından da söz etmek mümkün değildir. Sonuçta İslam onun nazarında kültürel boyutu olan bir oluşumdur.

Hadisler büyük oranda daha sonraki dönemlerde, gruplarca ihtiyaç duyulan konularda imal edilmiştir. Kanaatimize göre Goldziher'in hadislerin neredeyse tamamına yakınına şüphe ile bakmasının çıkış noktası ise siyasi rivayetlerdir.

Goldziher'e göre Peygamber'e isnad edilen hadislerin kaynaklarının başında Ahd-i Cedîd (İncil), Yeni Eflatuncu ve gnostik öğeler gelmektedir.

Her ne kadar Goldziher Batılı bir araştırmacı olsa da söz konusu İslam olunca, Hz. Âdem'den bu yana toplumlararası ortak değer ve kültürel etkileşimi göz ardı ederek bu değişimi, İslam'ın önceki kültürlerin bir ürünü olduğu iddiasına delil olarak kabul etmiştir.

139 bk. Goldziher, İslam Kültürü Araştırmaları, 83.

140 Goldziher, İslam Kültürü Araştırmaları, 84-89.

141 Goldziher, İlam Kültürü Araştırmaları, 105.

142 Goldziher, İslam Kültürü Araştırmaları, 106-126. 
Goldziher'in İslam kültürü araştırmalarının temelini aşırı genellemeci ve şüpheci usulü oluşturmaktadır. O bir hususu açıklarken hadis literatürü dışındaki kaynaklarda yer alan rivayetleri de kullanarak, adeta şüphesinin haklılığını ispata yönelik bir yol izlemiştir.

Goldziher 'Hadis Edebiyatı' başlığı altında temel İslami literatürü esas alarak ilk dönemden başlayarak hadis tarihi ve temel hadis kaynakları hakkında birtakım değerlendirmeler yapmıştır. Örneğin ona göre Mâlik b. Enes, asıl anlamda bir hadis musannıfı değildir. Ancak Mâlik b. Enes'in hadis malzemesine verdiği önem daha sonraki dönemin yolunu açmıştır.

Ahmed b. Hanbel'in Musned'i başta olmak üzere musnedlerin tarihi süreçteki gelişimi hakkında bilgi veren Goldziher, bu tür hadis kitaplarının 'ala'r-rcâl'/ ravilere göre tertip edildiğini ifade etmiştir. Onun bu değerlendirmesi klasik hadis usulü ile uyuşan teknik bir bilgidir. Goldziher'in hadis edebiyatının teknik yönleri ile ilgili verdiği bilgiler genelde Müslüman hadisçilerin değerlendirmesine aykırı bir durum içermemektedir.

Goldziher Buharî'nin 'es-Sahih'i hakkında teknik bilgiler verdikten sonra Sahih'in sadece bir hadis kitabı olmadığını, Buharî'nin kendisi gibi düşünenlerin ihtiyaçlarına cevap veren bir tarzla eserini hazırladığına inanır. Muslim'in 'esSahih'i hakkında da değerlendirmeler yapan Goldziher, onun da Buharî gibi fıkha hizmet amacı taşıdığını dile getirmiştir. Ayrıca o, gerek Buharî́nin ve gerekse Muslim'in kitaplarında yer verdiği ravilerin 'sika' olmasına özen gösterdiğini ifade etmiştir.

Goldziher'in 'Hadis Edebiyatı' hakkında yapmış olduğu şekle bağlı değerlendirmelerin klasik hadis usulü ile benzerlik gösteren yönünün olduğunu söylemek mümkündür. Ancak ona göre hangi hadis kitabı olursa olsun içerisinde yer alan rivayetlerin büyük bir çoğunluğu, daha sonraki dönemlerde imal edilerek Hz. Peygamber'e ref edilmiştir.

Goldziher'in daha sonraki dönemlerde kaleme aldığı makalelerinde onun $\mathrm{Hz}$. Peygamber, Kur'an ve hadisler hakkındaki temel düşüncelerinin değiştiğine dair bir kanaate ulaşma imkânımız olamamıştır. Sadece hadislerin tedvin ve tasnif tarihini daha öne çektiği, Musned'in belli bir mezhebi önceleyen hadis kitabı olmadığı ve sahabenin rivayeti konusundaki düşüncelerinin değiştiğini söylemek mümkündür.

Goldziher'in hadislere bir kültür malzemesi olarak, şüphe temelli yaklaşımından bir hadis usulü çıkarmanın zorluğu ortadadır. Ancak onun bazı tarihi ve mezhebi olayları irdelerken metin merkezli yaklaşımından bu işin uzmanlarının faydalanması söz konusu olabilir. 


\section{Kaynakça}

Akgün, Hüseyin. "Hadislerin Otantikliği Hususunda Bazı Oryantalistlerin Görüşleri ve 'Hadisin Özü' (Kern, Core) Kavramı”. Hikmet Yurdu Düşünce-Yorum Sosyal Bilimler Araştırma Dergisi 8/8 (2015): 75-97.

Akgün, Hüseyin. Goldziher ve Hadis. Ankara: Araştırma Yayınlar, 2019.

Akın, Nimetullah. "Hadislerin Yazılı Kaydı ve Literatür Esaslı Bir Disiplin Olma Süreci: A. Sprenger, I. Goldziher ve G. Schoeler'in Yaklaşımları". Hadis Tetkikleri Dergisi 6/1 (2008): 47-70.

Bağcı, H. Musa. Hadis Usulü ve Tarihi. Ankara: Bilay Yayınları, 2018.

Bağdâdî, Hatîb. Kitâbu'l-Kifâye fî ilmi'r-rivaye. Haydarabâd: Dâiretu'l-Meârif Usmaniyye, 1357.

Bağdâdî, Hatîb. Takyîdu'l-illm. Beyrut: Dâru ihya, 1974.

Buhârî, Ebû Abdillah Muhammed b. İsmail el-. el-Câmiu's-Sahîh. İstanbul: Çağrı Yayınları, $1413 / 1992$.

Canikli, Ilyas. Hadislere Göre Yöneticilere Itaatin Sınırları. Ankara: Ilahiyat Yayınları, 2004.

Cihan, Sadık. Uydurma Hadislerin Doğuşu Siyasi ve Sosyo-Politik Olaylarla IIlgisi. Samsun: Kardeşler Ofset, 1996.

Doğanay, Süleyman. Oryantalistlerin Hadisleri Tarihlendirme Yaklaşımları. İstanbul: Marmara Üniversitesi Illahiyat Fakültesi Yayınları, 2013.

Ebû Davud, Süleymân b. el-Eş'as b. İshâk es-Sicistânî el-Ezdî. es-Sunen. İstanbul: Çağrı, Yayınları, 1413/1992.

Goldzıher, Ignaz. Muhammedanische Studien. (İslam Kültürü Araştırmaları 1-2 çev. 1. cildi Cihad Tunç, 2. cildi ise Mehmed Said Hatiboğlu tarafından tercüme yapılmıştır. Ankara: Otto Yayınları, 2019.

Goldziher, Ignaz. Hadis Kültürü Araştırmaları. ed. Hüseyin Akgün, Ankara: Otto Yayınları, 2020.

Gül, Mutlu. vd., "Hadis İlmine Dair Kaleme Alınan Almanca Akademik Çalışmalar". Ihya Uluslararası İslam Araştırmaları Dergisi 6/1 (2020): 316-353.

Hatiboğlu, ỉbrahim. "Yakın Doğu Seyahati ve Eserler Bağlamında Ignaz Goldziher ve İslâm Dünyası ile Fikri Etkileşimi". Marife 2/3 (2002): 107-121.

Hatiboğlu, İbrahim. Çağdaşlaşma ve Hadis Tartışmaları. İstanbul: İz Yayıncılık, 2012.

Hatiboğlu, Mehmed S. "Batı'daki Hadis Çalışmaları Üzerine", İslami Araştırmalar 6/2 (1992): 105-113.

Hatiboğlu, Mehmed Said. Siyasi-İctimai Hadiselerle Hadis Münasebetleri. Ankara: Otto Yayınları, 2015.

Horovıtz, Josef. İslami Tarihçiliğin Doğuşu, çev. Ramazan Özmen vd., Ankara: Ankara Okulu Yayınları, 2019.

İlhan, Süleyman. "Akışkan Toplumda Kimlik İnşası: Geçişken, Eklektik, Ben Odaklı Kimlikler". FIrat Üniversitesi Sosyal Bilimler Dergisi 23/2 (2013): 233-246.

Kanarya, Bayram. İhtilaflı Hadisler-Imam Şâfiì'nin Yaklaşımı-. İstanbul: İz Yayıncılık, 2017. 
Kandemir, Mehmet Yaşar. Mevzû Hadisler Menşei Tanıma Yolları Tenkidi. Ankara: Diyanet İşleri Başkanlığı Yayınları, 1991.

Kırbaşoğlu, M. Hayri. Alternatif Hadis Metodolojisi. Ankara: Kitâbiyât, 2002.

Kızıl, Fatma. "Goldziher' den Schacht' a Oryantalist Literatürde Hadis ve Sünnet: Bir Okulun Yaşayan Geleneği". Hadis Tetkikleri Dergisi 7/2 (2009): 45-62.

Koçyiğit, Talat. "I. Goldziher'in Hadisle İlgili Bazı Görüşlerinin Tahlil ve Tenkidi", Ankara Üniversitesi Illahiyat Fakültesi Dergisi 15 (1967): 43-55.

Koçyiğit, Talat. Hadis Tarihi. Anakara: Ankara Üniversitesi İlahiyat Fakültesi Yayınları, 1998.

Kuzudişli, Bekir. "Oryantalizm ve Hadisle İlgilenen Bazı Oryantalistler". İstanbul Üniversitesi Ilahiyat Fakültesi Dergisi, 7 (2012): 141-172.

Müslim, Ebû'l-Hüseyn Müslim b. Haccâc. el-Câmıu's-Sahîh. İstanbul: Çağrı Yayınları, y.y:. $1413 / 1992$.

Nevevî, Şerhu Sahîhi Muslim. Beyrut: İhyâu't-turâsi'l-Arabî, ts.

Özafşar, Mehmet Emin. Oryantalist Yaklaşıma Itirazlar. Ankara: Otto Yayınları, 2015.

Özcan, Hıdır. “Oryantalizme Karşı Oksidentalizm: Hadis Oksidentalizmi-M. Fuad Sezgin ve M. Mustafa A'zami Örneği-. Hadis Tetkikleri Dergisi, 5/1 (2007): 7-31.

Özdemir, İlker. "Kültürlerarası İletişimin Önemi". Uluslararası Kıbrıs Üniversitesi Folklar/ Edebiyat Dergisi 17/66 (2011): 29-38.

Sarıçam, İbrahim vd., Ingiliz ve Alman Oryantalistlerin Hz. Muhammed Tasavvuru. Ankara: Nobel Yayınları, 2011.

Suiçmez,Yusuf. Sahabe ve Tabiin Sözlerinin Hz. Peygamber'e Nispeti. Ankara: Otto Yayınları, 2015.

Tekin, Dilek. "Batılı Araştırmacıların Hadislerin Yazılı-Şifahi' Rivayeti Meselesine Bakışları". Karadeniz Teknik Üniversitesi Ilahiyat Fakültesi Dergisi 2/1 (2015): 41-62.

Tirmizî, Ebû İsâ Muhammed b. İsa et-. es-Sunen. thk. İbrahim Adve Avz. b.y.: İstanbul: Çağrı Yayınları, 1413/1992.

Ünal, İsmail Hakkı. İmam Ebû Hanife'nin Hadis Anlayışı ve Hanefi Mezhebinin Hadis Metodu. Ankara: Diyanet İşleri Başkanlığı Yayınları, 1994.

Yücel, Ahmet. Hadis Tarihi. İstanbul: Marmara Üniversitesi Illahiyat Fakültesi Yayınları, 2011. 